\title{
TTN wt Allele
}

National Cancer Institute

\section{Source}

National Cancer Institute. ITN wt Allele. NCI Thesaurus. Code C101757.

Human TTN wild-type allele is located in the vicinity of $2 q 31$ and is approximately $305 \mathrm{~kb}$ in length. This allele, which encodes titin protein, is involved in both muscle filament structure and protein phosphorylation. Mutation of the gene is associated with hereditary myopathy with early respiratory failure, familial hypertrophic cardiomyopathy type 9 , cardiomyopathy dilated type 1G, tardive tibial muscular dystrophy, limb-girdle muscular dystrophy type 2J and early-onset myopathy with fatal cardiomyopathy. 